\title{
Historical colonisation patterns of Dolichospermum lemmermannii (Cyanobacteria) in a deep lake south of the Alps
}

\author{
Nico Salmaso, ${ }^{1 *}$ Adriano Boscaini, ${ }^{1}$ Camilla Capelli, ${ }^{1,2}$ Leonardo Cerasino, ${ }^{1}$ Manuela Milan,,${ }^{1,3}$ Sara Putelli, ${ }^{1,4}$ Monica Tolotti ${ }^{1}$ \\ ${ }^{1}$ IASMA Research and Innovation Centre, Istituto Agrario di S. Michele all'Adige - Fondazione E. Mach, Via E. Mach 1, 38010 S. Michele \\ all'Adige (TN), Italy; ${ }^{2}$ Department of Biology, University of Florence, Via La Pira 4, 50121 Firenze, Italy; ${ }^{3}$ Department of Ecology and \\ Environmental Science, Umeå University, Linneus väg 6, 90187 Umeå, Sweden; ${ }^{4}$ Department of Food, Environmental and Nutritional \\ Sciences, University of Milan, Via L. Mangiagalli 25, 20133 Milano, Italy \\ *Corresponding author: nico.salmaso@fmach.it
}

\begin{abstract}
Since the beginning of the 1990s, Lake Garda showed the appearance of extended surface water blooms of Dolichospermum lemmermannii (Nostocales, Cyanobacteria). Between the 1990s and the 2000s, the blooms appeared also in the other large lakes south of the Alps (Iseo, Como and Maggiore). Despite the sudden appearance of the blooms, the correct identification of the establishment time of the populations of Dolichospermum in the southern subalpine lake district remained unclear. In this work, the establishment of the populations of D. lemmermannii in Lake Garda has been evaluated by the direct counting of sub-fossil akinetes extracted from sediment cores, and by estimating the abundance of filaments germinated from sub-fossil viable akinetes. The two techniques provided comparable results, allowing locating the beginning of the establishment of Dolichospermum around the middle of the 1960s. Four strains of Dolichospermum germinated from akinetes isolated from the core sediments between around the 1989 and 2012 did not show any mutation or recombination signal in the rроB gene sequences, suggesting a strong founder effect. The establishment of Dolichospermum coincided with the beginning of the rapid increase of total phosphorus as inferred from the distribution of sub-fossil diatoms in the sediment core. These results supported the hypothesis of a strong link between the shift of Lake Garda from ultraoligotrophy/oligotrophy to oligo-mesotrophy and the development of Dolichospermum. This colonisation pattern was possibly reinforced by the increase in the water temperatures in the subalpine lake district during the last 3 decades. In warmer lakes, gas-vacuolated Nostocales are favoured by high replication rates and, in particular, by their ability to control vertical movements in stratified water columns. This allows these species to exploit the gradients of light and nutrients, giving them a competitive advantage compared to other species. From a management point of view, the control and decrease of Dolichospermum should be obtained through the reduction and control of nutrient loads to the lake.
\end{abstract}

Key words: Cyanobacteria; Dolichospermum; invasion; Lake Garda; akinetes; resurrection ecology.

Received: July 2015. Accepted: November 2015.

\section{INTRODUCTION}

Cyanobacteria are the most primitive and ancient photo-oxygenic organisms on earth. With a variety of morphologically different types, they occur in aquatic and terrestrial habitats, as well as in extreme environments such as ultraoligotrophic oceans (Seymour, 2014), soil crusts in semi-arid areas (Metcalf et al., 2012), and geothermal hot springs (Ward and Castenholz, 2012). In freshwater ecosystems, they can dominate the phytoplankton assemblages forming blooms in the water column or at the surface of lakes and rivers. This ability to colonise and dominate virtually every habitat on earth is due to their long evolutionary history (Tomitani et al., 2006) and to a number of adaptations that render them competitively superior to many eukaryotic phytoplankton groups (Dokulil and Teubner, 2000). In this regard, cyanobacteria are one of the major eubacterial lineages. The diversity within this group includes morphological characters (from single cells to branching filaments), the formation of specialized cells (akinetes and heterocytes) and cell structures (aerotopes or gas-vesicles), and physiology (nitrogen fixation, heterotrophy, motility) (Graham et al., 2009).

The growth and dominance of cyanobacteria have important consequences on the characteristics of water bodies. Along with effects in common with other eukaryotic algae (decrease of water transparency, increase of $\mathrm{pH}$, alteration of biogeochemical cycles), cyanobacteria have further critical impacts, which include changes in the biomass size spectrum and edibility by zooplankton, and the production of an impressive range of secondary toxic metabolites (Sukenik et al., 2015), including hepatotoxins and neurotoxins (Metcalf and Codd, 2012). The massive development of this algal group is considered as one of the principal problems for the utilisation of water resources, with possible impacts on human health (Chorus and Bartram, 1999; Ibelings et al., 2014).

The cyanobacterial species belonging to the Nostocales have the ability to develop specialized cells with distinctive morphological and physiological adaptations for 
the fixation of atmospheric nitrogen (heterocytes) and survival in harsh environmental conditions while quiescent in bottom sediments (akinetes). Mature akinetes have a normal cell wall surrounded by a thick three layered coat and a conspicuous granulation due to high concentrations of glycogen and cyanophycin, a nitrogen-storage polymer (Lee, 2008; Meeks et al., 2002). The loss of gas-vesicles and the increase in cytoplasmic density favour the sinking of overwintering akinetes to the bottom sediments. Functionally, akinetes act as spores. They differentiate from vegetative cells by increasing in size and thickening the walls, and by drastically reducing photosynthetic and respiratory capabilities. For example, studies carried out on Aphanizomenon ovalisporum FORTI showed that mature akinetes isolated from cultures maintained only residual photosynthetic activity, as indicated by very low values of maximal photosynthetic quantum yields (Sukenik et al., 2007). The rearrangement of the photosynthetic apparatus with the maturation of akinetes is essential to enter the dormant period, assuring, at the same time, a quick recovery of photosynthesis after germination. The environmental factors activating the formation of akinetes differ between species and even strains. After the examination of several case studies, Kaplan-Levy et al. (2010) identified light intensity as the major factor triggering the formation of akinetes, though other factors, such as light quality, temperature, limitation of phosphorus and other nutrients and micronutrients, were considered important in many other instances. On the other hand, the germination of akinetes is controlled by various environmental factors, including temperature, nutrients, day length, penetration of light to the sediments and intensity of turbulence inducing resuspension near the bottom sediments (Kaplan-Levy et al., 2010).

In general, akinete formation takes place at the end of the growth season. Reynolds (1972) observed akinetes in water columns after a dense Anabaena population had decreased. Kim et al. (2005) found a gradual increase in akinete cell densities in the surface sediments after a drop of Anabaena flos-aquae BRÉBISSON EX BORNET \& FlauHault densities. Nevertheless, studying the seasonal dynamics of Anabaena flos-aquae, Kravchuk et al. (2006) identified two types of akinetes. While in early summer akinetes germinated in water column soon after differentiation, contributing to the vegetative reproduction of populations, in late summer akinetes were deposited to bottom sediments, acting as resting stages.

Along with other algal remains, the study of akinetes in core sediments may provide more comprehensive knowledge of past lake phytoplankton assemblages and ecological conditions (Livingstone, 1984). Combined with other paleolimnological proxies, sub-fossil akinetes may contribute to the assessment of the effects of eutrophication and climate change on lake biota. Akinetes are very resistant to degradation. Fossil akinetes have been identified in 1.6 to 2.1 billion years old cherts in different regions of the world (Tomitani et al., 2006).

At the beginning of the 1990s, Lake Garda showed a quick and unexpected appearance of surface blooms of a pelagic Nostocales, Dolichospermum lemmermannii (P.G. Richter) P. WACKLin, L. Hoffmann \& J. KomÁreK. Since their first records, the blooms raised major concerns because of the potential toxigenic effects and the impacts on the tourism economy. The exact timing of the colonisation, however, remained uncertain because it was based almost exclusively on the detection of the surface water blooms and on a few scattered phytoplankton analyses available before the 1990s. Moreover, since the distribution of Dolichospermum is clearly localised in the temperate and boreal regions (Salmaso et al., 2015a), the north to south colonisation pattern of this species contrasted with the prevalent south to north invasion routes of tropical species to the European continent (Sukenik et $a l ., 2012)$. On the other hand, many studies demonstrated that the spread of cyanobacteria can be favoured, besides by eutrophication, by the increase of water temperatures caused by global warming (Paerl and Huisman, 2009; Mehnert et al., 2010). In a recent work, (Salmaso et al., 2015a) hypothesised that the increase of Dolichospermum in Lake Garda could be ascribed to the increase of nutrients observed during the last 40 years. This hypothesis will be further explored in this study, by comparing the distribution of sub-fossil akinetes of D. lemmermannii in the deep sediments of the lake with the secular trend of phosphorus recently inferred from sub-fossil diatoms by Milan et al. (2015).

Specific objectives of this work include: i) the reconstruction of the historical colonisation patterns of Dolichospermum lemmermannii in Lake Garda based on the analyses of sub-fossil akinetes and its interpretation based on the secular changes in P-availability and longterm changes in water temperatures; ii) the assessment of the comparability of results obtained from the direct counting of sub-fossil akinetes extracted from sediments and the estimation of the abundances of strains germinated from sediments; iii) the phylogenetic confirmation of the taxonomic identity of recent and ancient populations of $D$. lemmermannii isolated from environmental samples and originated from the germination of akinetes from the sediment layers, respectively.

\section{METHODS}

\section{Study site}

Lake Garda is the largest Italian lake. It has a volume of $49 \times 10^{9} \mathrm{~m}^{3}$, a surface of $368 \mathrm{~km}^{2}$, and a maximum depth of $350 \mathrm{~m}$. Thanks to attractive landscape and water quality, 
the lake is an important resource for recreation and tourism. Moreover, its waters are also used for agriculture, industry, fishery and drinking. Owing to its climatic location, Lake Garda should be classified as warm monomictic. In this category, lakes circulate completely once a year in the winter at or above $4^{\circ} \mathrm{C}$, showing stable stratification for the remainder of the year. Nevertheless, owing to its great depth, complete mixing can occur only irregularly, after cold winters (oligomixis). Since the beginning of the 1990s, Lake Garda has been regularly investigated with monthly samplings in a station located at the deepest point of the basin (45.69 N, 10.72 E). The Lake Garda sampling station was included in the Italian Network for the Long Term Ecological Research in 2007 (LTER, www.lteritalia.it).

\section{Climatic, environmental, and phytoplankton data}

Mean monthly homogenised air temperatures were obtained from the long-term instrumental climate data recorded in the Alpine region in the framework of the project HISTALP (Auer et al., 2007). In this work, we have considered the temperatures recorded at Torbole - Riva del Garda, which is the nearest HISTALP meteorological station to the lake sampling point (ca. $20 \mathrm{~km}$ north). Since a preliminary interpolation by loess of the long-term temporal development of the air temperatures showed the presence of abrupt changes, the data were analysed by piecewise regressions. The selection of the break-point was guided by computing the residual standard error of several two-segment piecewise models and by the results of the loess interpolation (R Core Team, 2015).

The collection of samples and measurements in the water layers 0-2, 9-10 and 19-21 m were made at monthly intervals since 1991 in the LTER station. Samples for the analysis of phytoplankton abundance and nutrients were collected since 1993 and 1995, respectively. Vertical profiles of water temperature were measured with multi-parameter probes (Idronaut Ocean Seven 401 and 316Plus, and Seabird SBE 19-03) (Sharma et al., 2015). The significance of the linear long-term trend of annual mean water temperatures in the layer $0-50 \mathrm{~m}$ was tested with the Mann-Kendall (MK) test, whereas the trend coefficients were estimated with the non-parametric Theil-Sen estimate of slope following the procedures described in Salmaso and Mosello (2010). Statistical analyses were carried out with R 3.2.2 (R Core Team, 2015). Nitrate nitrogen $\left(\mathrm{NO}_{3}-\mathrm{N}\right)$ and total phosphorus (TP) were analysed using standard methods (Cerasino and Salmaso, 2012). Phytoplankton counting was carried out using the Utermöhl method as described in Salmaso (2010).

\section{Sediment sampling, and akinetes analyses}

A sediment core was collected with a gravity Kajak corer (UWITEC, Mondsee, Austria) at the LTER station of Lake Garda on 11 March 2014. The core was vertically extruded and sliced in the laboratory at $0.5 \mathrm{~cm}$ intervals from 0 to $30 \mathrm{~cm}$ and at $1 \mathrm{~cm}$ intervals from $31 \mathrm{~cm}$ down to the core bottom $(45 \mathrm{~cm})$. Hereafter the layers will be indicated by their mid-depth (e.g., 1-1.5 cm: $1.25 \mathrm{~cm})$. Water content was determined after drying $\sim 2 \mathrm{~g}$ of wet sediment at $105^{\circ} \mathrm{C}$ for $24 \mathrm{~h}$.

The direct microscopic analysis of akinetes is disturbed by the presence of sediments and organic material (including siliceous diatoms). This is especially true in low productivity, nutrient-poor lakes, where the abundance of akinetes is low. In such environments, a reliable counting could require a pre-treatment of the samples aimed at removing carbonate and silicate crystalline material, and diatom carpets. Before observation, the sediment samples were therefore processed adapting standard laboratory methods used for pollen analysis (Faegri and Iverson, 1989). Examples of applications of these methods in the analyses of sub-fossil akinetes and cyanobacteria are reported in Platt Bradbury et al. (2004), Danielsen (2009), Menozzi et al. (2010) and Miras et al. (2015). For each sediment layer, subsamples of ca. $2 \mathrm{~g}$ of fresh sediment were put in $15 \mathrm{~mL}$ plastic test tubes. The sediment was initially processed with $10 \%$ hydrochloric acid $(\mathrm{HCl})$ for the removal of carbonates. For the removal of organic matter, $10 \mathrm{~mL} 10 \% \mathrm{KOH}$ were added to the test tubes placed in a boiling water bath for $10 \mathrm{~min}$, stirring slowly. The siliceous material was removed by adding hydrofluoric acid (HF). Compared with standard methods, the concentrations of HF were reduced to $10 \%$ to reduce the risk in laboratory procedures. The fluorosilicates gels formed during the reaction with HF were removed by adding $10 \mathrm{~mL}$ hot $10 \% \mathrm{HCl}$ for $20 \mathrm{~min}$. After the treatment with $\mathrm{HCl}, \mathrm{KOH}$ and $\mathrm{HF}$, the samples were centrifuged at $3000 \times \mathrm{g}$ for 3-4 minutes, pouring away the supernatant. After the last treatment with HF, the final residue was diluted in $100 \mathrm{~mL}$ water and fixed with Lugol's solution. The samples, diluted 1:20, were transferred into $10 \mathrm{~mL}$ sedimentation chambers and analysed by an inverted microscope at $400 \times$.

The enumeration of akinetes was carried out analysing the whole bottom chamber of two replicates (Supplementary Fig. 1). The application of this method allowed obtaining clean samples, rich in akinetes. Furthermore, after this treatment the akinetes were not hidden by siliceous frustules, therefore reducing the risk of misidentification, which is particularly high in lakes rich in diatoms, such as Lake Garda (Salmaso, 2010). During this research, the reliability of the method was tested with a parallel counting of akinetes on treated (T, $n=4)$ and non treated (NT, $n=8)$ fresh sediment samples (without step 2 in Supplementary Fig. 1) extracted from a core rich in akinetes collected in Lake Balaton in November 2010 within the framework of the project EULAKES (www.eulakes.eu). The concentrations (average 
\pm SE) of akinetes in the $\mathrm{T}$ and NT samples were equivalent $\left(83 \pm 9\right.$ and $88 \pm 6$ akinetes $\mathrm{mg}^{-1}$ fresh sample, respectively; ANOVA, $\mathrm{F}_{1,10}=0.23, \mathrm{P}>0.60$ ).

The germination of filaments from sub-fossil akinetes was obtained using ca. $4 \mathrm{~g}$ of fresh sediment inoculated in $100 \mathrm{~mL}$ conical flasks. A final volume of $60 \mathrm{~mL}$ was obtained by adding ASM- 1 culture media (Carmichael and Gorham, 1974). The cultures were added with actidione (cycloheximide, $250 \mathrm{mg} \mathrm{L}^{-1}$ ) as an inhibitor of eukaryotic growth (Livingstone and Jaworski, 1980). The flasks were incubated in a growth cabinet at $20^{\circ} \mathrm{C}$ under continuous irradiance with day light florescent lamps at $85 \mu \mathrm{mol} \mathrm{m}^{-2}$ $\mathrm{s}^{-1}$. The germination of akinetes was observed up to 16-21 days. Later on, the culture media with germinated vegetative cells were harvested and preserved in $100 \mathrm{~mL}$ bottles fixed with Lugol's solution. After dilution 1:40, the subsamples were transferred into $10 \mathrm{~mL}$ sedimentation chambers. The enumeration of the germinated cells was carried out with an inverted microscope by analysing the whole bottom chamber of 4-6 replicates (Supplementary Fig. 2). Owing to the successive vegetative replication after the initial germination, the final densities of the cells recorded in the flasks were only roughly proportional to the initial number of akinetes in the sediments. On the other hand, one of the advantages of this method is to allow resurrection of ancient akinete-forming populations.

\section{Core dating and analysis}

The 2014 sediment core was dated by parallelisation (Thompson et al., 2012) with a core collected at the same sampling point in October 2009. The 2014 and the 2009 cores showed a well resolved and comparable macroscopic layering, and very similar depth profiles of water content $(r=0.94, \mathrm{P}<0.01)$. The core collected in 2009, and used for the parallelization, was dated analysing radionuclide activity of ${ }^{210} \mathrm{~Pb},{ }^{226} \mathrm{Ra},{ }^{137} \mathrm{Cs}$ and ${ }^{241} \mathrm{Am}$ in subsamples of individual sections, as described in Milan et al. (2015). The radionuclides allowed dating the core until the end of 1800s $(26-27 \mathrm{~cm})$. The dating of the deeper layers was estimated based on the ${ }^{14} \mathrm{C}$ analysis made on a vegetable remain isolated at $48.5 \mathrm{~cm}$, which was dated back to 1388-1448 AD (Milan et al., 2015). In order to assign an age to each sediment layer of the core collected in 2014, a LOESS interpolation of radiometrically determined dates for non-contiguous sediment layers was performed using R 3.2.2 (R Core Team, 2015).

In this work, we will also report additional results regarding the bacterial photosynthetic pigments and secular lake TP concentrations reconstructed from sub-fossil diatoms obtained from the analyses of the 2009 core (Milan et al., 2015). Photosynthetic pigments were determined after sonication of sediments, extraction with acetone and analysis by light spectrometry and HPLC. Sub-fossil diatom frustules were cleaned following standard proce- dures (Battarbee et al., 2001). Diatom-inferred total phosphorus concentrations (DI-TP) were reconstructed using a weighted-average regression model with inverse deshrinking that was calibrated against the Northwest European training set (NWEu-TP) (Bennion et al., 1996). The detailed description of these procedures was reported in Milan et al. (2015).

\section{Isolation of Dolichospermum strains and genetic analyses}

Single filaments of germinated Dolichospermum were isolated from the cultures (stage 2 in Supplementary Fig. 2) obtained from the layers 1.25, 3.25, 4.25 and 6.25 , corresponding to the years 2012, 2005, 2000, and 1989, respectively. Compared with filaments isolated from environmental samples, the individuals obtained from the germinated akinetes were more difficult to grow. After washing 3-4 times, the single filaments were grown in $\mathrm{Z} 8$ medium at $20^{\circ} \mathrm{C}$ under $16: 8 \mathrm{~h}$ light:dark photoperiod and at $25 \mu \mathrm{mol} \mathrm{m}{ }^{-2} \mathrm{~s}^{-1}$. DNA extraction of the cultures containing the single strains was carried out following Shams et al. (2014). Phylogenetic analyses were carried out by the amplification of the $r p o B$ gene encoding the $\beta$ subunit of RNA polymerase. $r p o B$ was amplified with the primers rpoBanaF and rpoBanaR, following a modified protocol described in Rajaniemi et al. (2005). The reaction mix $(20 \mu \mathrm{L})$, contained $1 \mathrm{X}$ Optimized DyNAzyme PCR Buffer, $0.25 \mathrm{mM}$ dNTPs mix, $0.4 \mathrm{U}$ of DyNAzyme II DNA Polymerase, $0.5 \mu \mathrm{M}$ of the two primers, and 5-20 ng DNA templates. PCR amplification involved an initial denaturation for $5 \mathrm{~min}$ at $94^{\circ} \mathrm{C}, 30 \mathrm{cy}$ cles of amplification: $1 \mathrm{~min}$ at $94^{\circ} \mathrm{C}, 1.5 \mathrm{~min}$ at $59^{\circ} \mathrm{C}$ and $2 \mathrm{~min}$ at $68^{\circ} \mathrm{C}$, and a final elongation for $7 \mathrm{~min}$ at $68^{\circ} \mathrm{C}$. PCR products were separated by $1 \%$ agarose gel electrophoresis stained with ethidium bromide. The rроB gene was sequenced with the same primers used in the PCR following the methods described in Shams et al. (2014). The sequences (564-576 bp long) were deposited to the European Nucleotide Archive (ENA) with accession numbers LN871489- LN871492.

\section{Phylogenetic analysis}

The rpoB sequences of the germinated Dolichospermum strains were compared with other 2 sequences of $D$. lemmermannii isolated from recent pelagic samples collected in Lake Garda in 2013 and 2014 (accession numbers LN871471 and LN871475, respectively; Salmaso et al., 2015a) and other Dolichospermum species from GenBank. Microcystis aeruginosa (KüTZING) KÜTZING (EU151907) was included as outgroup. All the steps in the phylogenetic analysis were performed with the free statistical software R 3.2.2 (R Core Team, 2015). Sequences were aligned with MUSCLE (Edgar, 2004), and 
poorly aligned positions and divergent regions were eliminated using Aliscore (Misof and Misof, 2009). Phylogenetic trees were computed by Maximum Likelihood (ML) with 1000 bootstrap (BS) replicates using the package phangorn. The analysis of DNA substitution models indicated in the $\mathrm{K} 80+\mathrm{G}$ the best-fitting evolutionary model for the $r p o B$ gene.

\section{RESULTS}

\section{Long term development of air and water temperatures}

The long-term development of the mean annual air temperatures recorded at the northern border of the lake showed an overall tendency to increase (Fig. 1A). The interpolation by the loess function suggested the existence of at least two different linear relationships in the data, with an abrupt change of slopes around the first half of the 1960s. The piecewise regression $\left(\mathrm{R}^{2}=0.60, \mathrm{P}<0.001\right)$ indicated an increase in air temperature around $0.07^{\circ} \mathrm{C}$ per decade between the end of the $1800 \mathrm{~s}$ and 1965 , and $0.45^{\circ} \mathrm{C}$ per decade in the successive years. Overall, since 1965 , the mean annual air temperatures increased from around $12.5^{\circ} \mathrm{C}$ to over $14^{\circ} \mathrm{C}$.

The long term change of the lake water temperatures was evaluated in the mixolimnetic layer, between 0 and
$50 \mathrm{~m}$ (Fig. 1B). Since 1991, this layer underwent complete cooling every year, thus representing the part of the lake most affected by the winter climate. In this layer, the annual mean water temperatures showed a significant increase (Kendall's tau $0.34, \mathrm{P}<0.05$ ), at a rate of $0.24^{\circ} \mathrm{C}$ per decade $(\mathrm{P}<0.05)$.

\section{Nutrients}

In the first half of the 1970s, total phosphorus concentrations measured in the whole water column $(0-350 \mathrm{~m})$ were around 5-10 $\mu \mathrm{g} \mathrm{P} \mathrm{L}^{-1}$ (Fig. 2A). In the following 30 years, TP increased continuously, until reaching concentrations between 20 and $25 \mu \mathrm{g} \mathrm{P} \mathrm{L} \mathrm{P}^{-1}$ around 2000. More recently (i.e., after 2005), TP showed a slow tendency to decrease. Present concentrations are around $18 \mu \mathrm{g} \mathrm{P} \mathrm{L} \mathrm{L}^{-1}$ (Fig. 2A). During the coldest months, in the epilimnetic layers TP reached homogeneous concentrations from the surface to the bottom only during complete overturn. During summer stratification, epilimnetic TP concentrations were generally between 5 and $10 \mu \mathrm{g} \mathrm{P} \mathrm{L}^{-1}$ (Salmaso, 2011).

The pattern characterizing the long-term temporal changes of TP evaluated on the basis of chemical analyses (Fig. 2A) was confirmed by the TP values inferred from the composition of sub-fossil diatoms analysed in the core collected in 2009 (Fig. 3). The reconstruction of diatom-
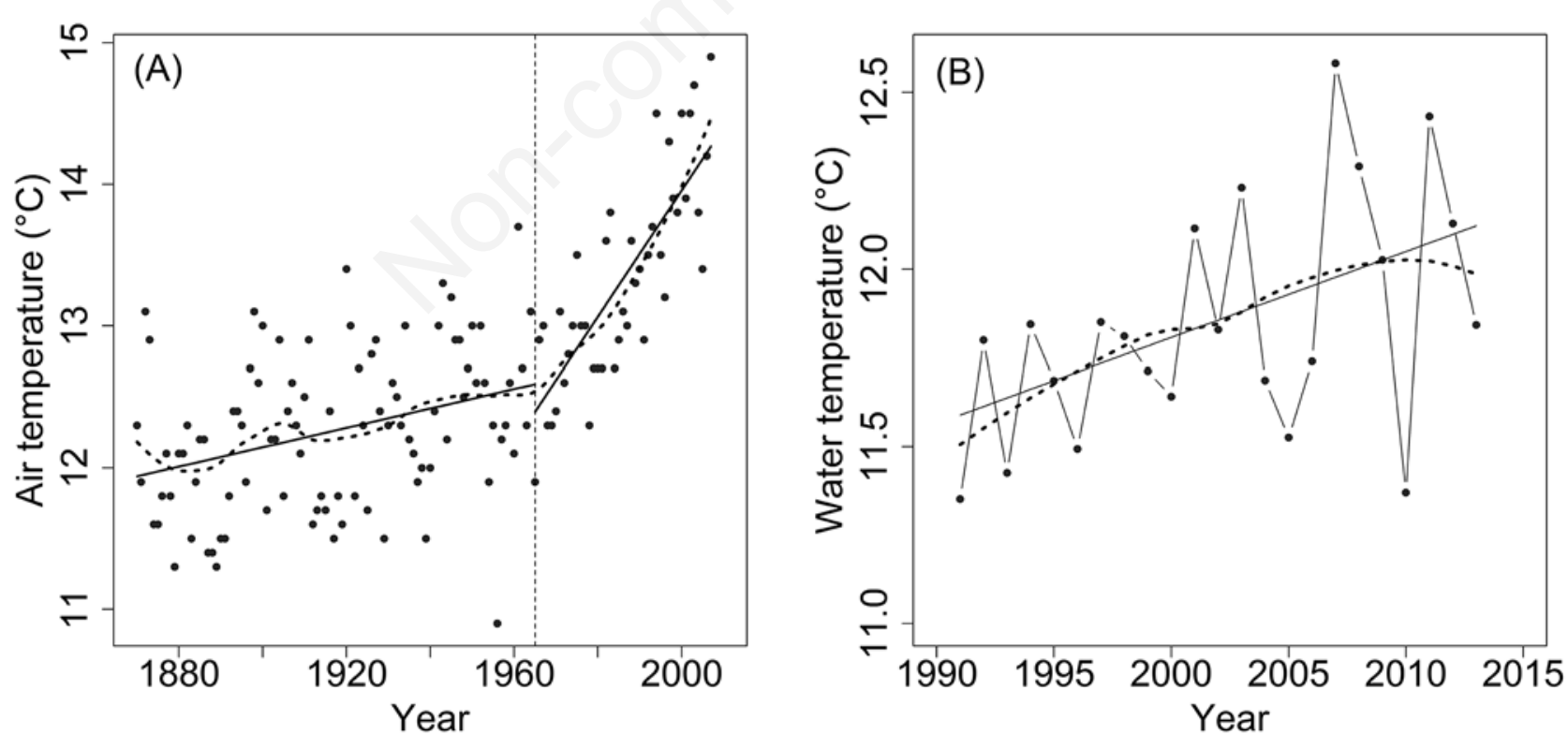

Fig. 1. Long-term temporal development of the mean annual values of (A) air temperatures recorded at the HISTALP meteorological station of Torbole - Riva del Garda, around $20 \mathrm{~km}$ north the sampling station; the interpolation by the 2-segmented line was obtained by a piece-wise regression. (B) Annual mean water temperatures in the layer between 0 and $50 \mathrm{~m}$ recorded in the LTER station of Lake Garda; the continuous line shows the linear trend obtained by the Theil-Sen estimate of slope. In (A) and (B) the series have been smoothed using the LOESS procedure (dashed lines). 
inferred TP concentrations showed that, at least since the last period of the Middle Ages and until the beginning of the 1960s, Lake Garda was characterised by near ultra-

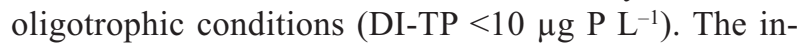
crease of DI-TP began only during the second half of the
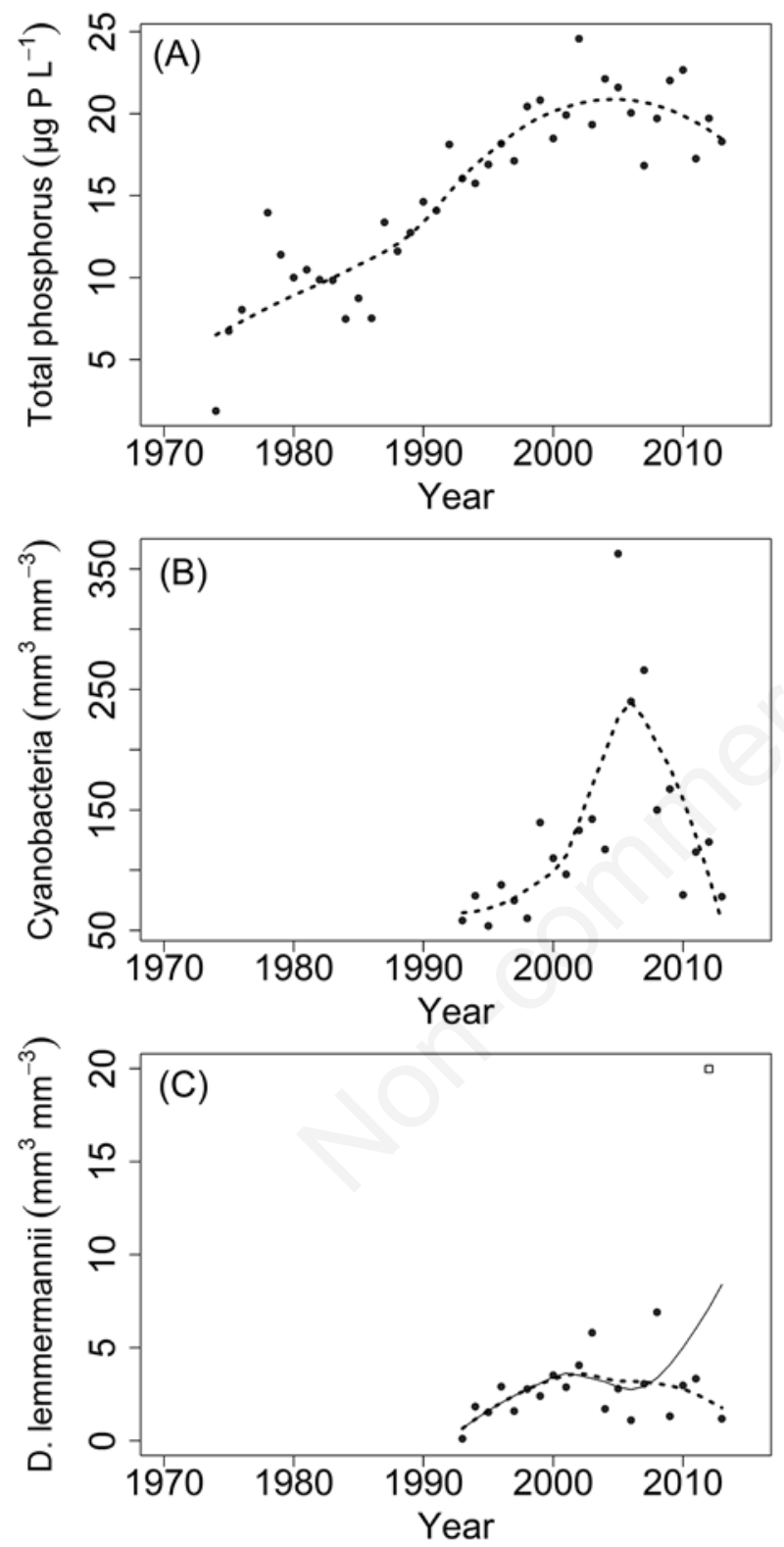

Fig. 2. Long-term temporal development of the mean annual values of (A) total phosphorus in the whole water column (0$350 \mathrm{~m}$ ), and (B) cyanobacteria and (C) Dolichospermum lemmermannii in the trophogenic layers $(0-20 \mathrm{~m})$. In (A) the data before 1995 were redrawn from Salmaso and Mosello (2010). The series have been smoothed using the LOESS procedure (dashed lines). In (C), the continuous line reports the LOESS smoothing computed including the outlier.
1960 s, in line with the results obtained by the modern limnological analyses (Mosello and Giussani, 1997; Fig. 2A and Fig. 3). Though less distinct, this pattern was confirmed also by the TP values inferred by pigment analyses (Car-TP; Fig. 3).

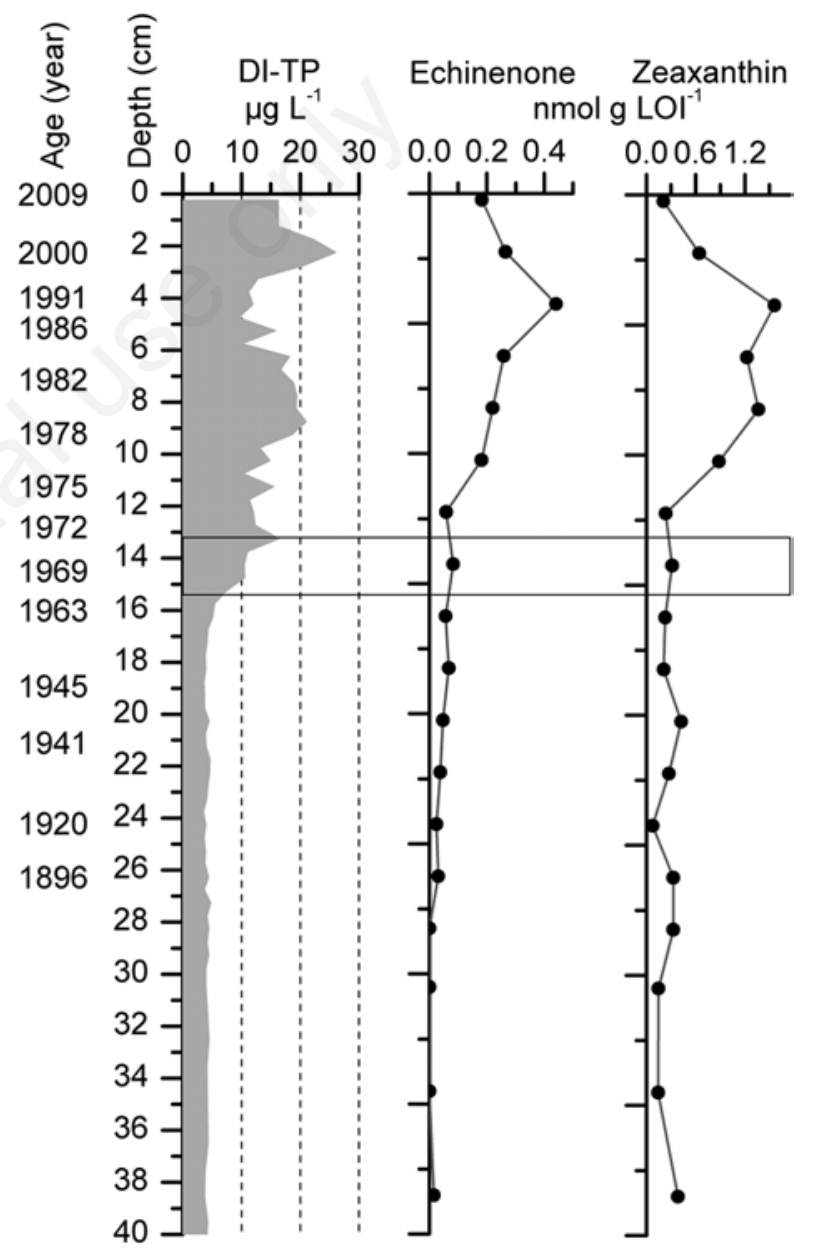

Fig. 3. Depth profiles of reconstructed phosphorus and sub-fossil cyanobacterial pigments in the sediment core collected from the deepest point of Lake Garda in 2009. DI-TP are TP concentrations reconstructed from sediment diatom abundance data using an inverted weighted averaging procedure based on the North West Europe training set (Milan et al., 2015). Echinenone is a xanthophyll synthesised exclusively by some cyanobacteria. While zeaxanthin is a major pigment in cyanobacteria, it can be present in low quantities in most other eukaryotic phytoplankton species (Takaichi, 2011; Milan et al., 2015). LOI, loss-on-ignition; the box highlights the first establishment of Dolichospermum lemmermannii. 
In the whole water column, the average annual concentrations of nitrates (the prevalent $\mathrm{N}$-compound) between 1996 and 2013 ranged between 290 and $400 \mu \mathrm{g} \mathrm{L}^{-1}$. In the trophogenic layers $(0-20 \mathrm{~m})$, annual averages of $\mathrm{NO}_{3}-\mathrm{N}$ generally varied from 200 to $260 \mu \mathrm{g} \mathrm{N} \mathrm{L}{ }^{-1}$, without showing any apparent trend in the analysed period $(\mathrm{P} » 0.1)$.

\section{Cyanobacteria}

Since the beginning of phytoplankton analyses, the annual averages of the cyanobacteria biovolumes showed a gradual increase from $50-100 \mathrm{~mm}^{3} \mathrm{~m}^{-3}$ until $250-350 \mathrm{~mm}^{3}$ $\mathrm{m}^{-3}$ in the middle of 2000s (Fig. 2B). In the successive period, cyanobacteria showed a dramatic decrease, until reaching biovolumes similar to those measured at the beginning of the 1990s.

The analyses of phytoplankton allowed inferring the response of cyanobacteria to the changes of phosphorus in the last 20 years. On a multi-decadal scale, zeaxanthin and echinenone, which are carotenoids typically produced by cyanobacteria, showed a sudden increase in the second half of the 1970s (Fig. 3). In the previous period, both pigments were measured with very low or undetectable values. The increase of cyanobacteria as inferred from these two proxies was shifted forward by around 10 years compared with the increase of DI-TP (Fig. 3). It is worth considering that both zeaxanthin and echinenone did show a tendency to decrease during and after the first half of 2000 s, therefore confirming the recent tendency of cyanobacterial decrease estimated from the algal counts.

\section{Dolichospermum lemmermannii: long-term temporal development and water blooms}

The annual means of Dolichospermum lemmermannii biovolume were over one order of magnitude lower than those of total cyanobacteria (Fig. 2C). Excluding the higher biovolume value computed in 2012, the long-term temporal pattern of $D$. lemmermannii biovolume was comparable to that of total cyanobacteria.

The very low annual average biovolumes of $D$. lemmermannii at the beginning of the 1990s were consistent with the timing in the appearance of the first visible water bloom. The surface accumulation of filaments of D. lemmermannii was observed for the first time in the shallower and wind sheltered E-basin (Salmaso et al., 1994). In the successive years, and quite rapidly, the water blooms expanded over the whole lake, including the northernmost and deeper zone. The blooms, which were observed both in the central zones and along the lake shores, were usually accumulated by the wind in sheltered bays and harbours. The episodes were always observed between early summer and autumn. A careful investigation among the scientists studying the lake since the 1950s and the fisherman allowed confirming the absence of the water blooms of Dolichospermum before the 1990s (Salmaso et al., 1994). Between the second half of the 1990s and 2000s, D. lemmermannii appeared also in the other largest lakes south of the Alps, i.e., lakes Iseo, Como and Maggiore (Garibaldi et al., 2003; Mosello et al., 2010; Salmaso, 2010; Callieri et al., 2014).

\section{Historical distribution of akinetes and resurrected populations of Dolichospermum}

The last measurable quantity of sub-fossil akinetes in the core collected in 2014 was found at $16.75 \mathrm{~cm}$ (1965; Fig. 4A, Supplementary Fig. 3). Repeated counts made on layers corresponding to the previous period, between 1935 and 1961, were negative. Since 1965, the number of akinetes remained practically constant until the end of the 1970s. Since then, akinetes abundance suddenly and fastly increased until 2007, then began to decrease. The morphology and morphometry of akinetes in the sediments were the same as those found in the pelagic samples, with length and width around 14-20 $\mu \mathrm{m}$ and 6.5-8.5 $\mu \mathrm{m}$, respectively (Salmaso et al., 2015a).

The germination of akinetes, with the corresponding growth of resurrected populations of Dolichospermum, was observed between the surface and the core depth of $14.25 \mathrm{~cm}$ (1971; Fig. 4B). Similarly to what was observed with the direct counting of akinetes (Fig. 4A), the new filaments developed with constant and low abundances until 1985. In the following periods, densities steadily increased till the end of 2000s. The counts corresponding to the uppermost analysed layer (dating 2012) showed a decrease in the cell abundances (Fig. 4B). The vegetative cells in the filaments presented characteristics fully compatible with the physiographic characteristics of $D$. lemmermannii. Nevertheless, compared with the natural populations, the formation of akinetes and heterocytes was usually not observed in the sediment cultures.

The phylogenetic analyses allowed clearly confirming the taxonomic nature of the sub-fossil populations of Dolichospermum germinated from the sediments. The four $r p o B$ sequences of the resurrected strains corresponding to the years 1989, 2000, 2005 and 2012 were identical. These four strains formed a compact clade along with the strains of $D$. lemmermannii isolated in the pelagic samples of Lake Garda and other two strains isolated in N-Europe (Fig. 5). The other Dolichospermum species formed different separated clades.

\section{DISCUSSION}

The analyses of the distribution of the sub-fossil akinetes preserved in a sediment core collected in 2014 allowed to reconstruct the colonisation pattern of Dolichospermum lemmermannii in Lake Garda. The clear 
identification of the beginning of the colonisation is a necessary requirement to interpret the causes that favoured the introduction and the successive rapid spread of this Nostocales in Lake Garda and in the whole southern subalpine lake district. The two laboratory procedures used to estimate the quantitative presence of Dolichospermum in the sediment layers provided consistent and reproducible results. The direct determination of akinetes in

(A)

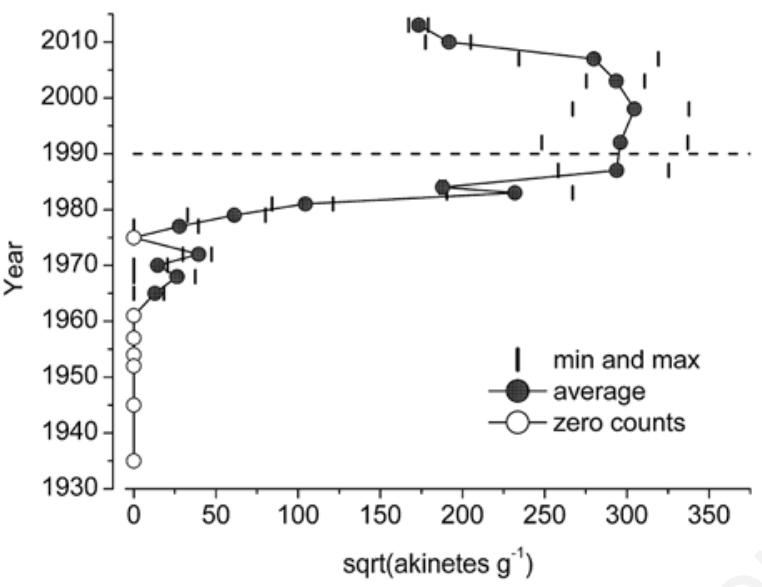

(B)

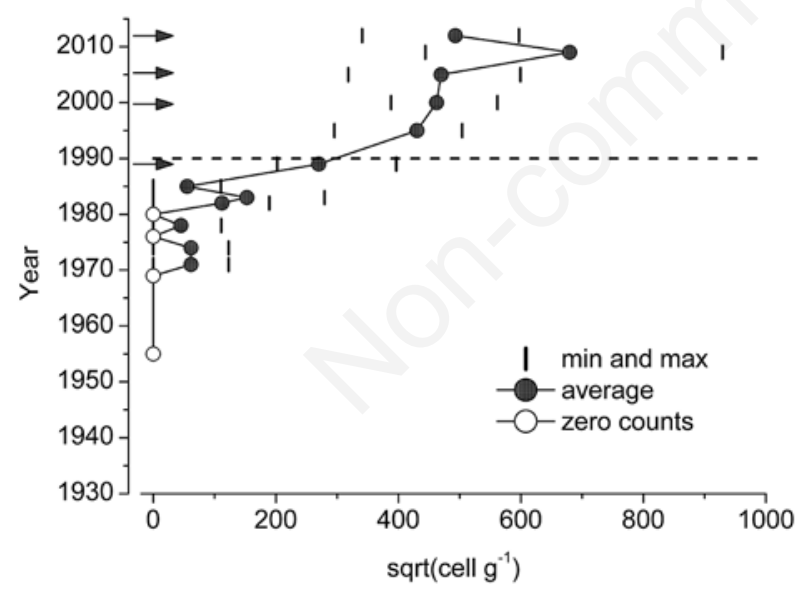

Fig. 4. Vertical distribution of (A) sub-fossil akinetes and (B) cells developed and reproduced from the germination of viable akinetes of Dolichospermum lemmermannii preserved in the sediment layers. The densities have been transformed by square root. The horizontal dashed lines indicate the period of first appearance of the blooms. In (B), the isolation and resurrection in culture conditions of single ancient Dolichospermum strains was obtained from the layers indicated with the arrows, which correspond to the years 2012, 2005, 2000, and 1989. The counting of akinetes in the sediments and the counting of the cells originated from the germination of akinetes indicated the beginning of the colonisation of Dolichospermum in the middle of the 1960s and in 1971, respectively. cleaned sediments and the counting of the cells germinated from viable akinetes indicated the beginning of the colonisation in the middle of the 1960s and in 1971, respectively. Though the discrepancy between the two methods, around 5 years, was very limited we cannot exclude the possible presence of a few other akinetes also in the older sediment layers. Nevertheless, both the consistency of the two methods in detecting the presence of akinetes, and the very rapid increase of akinetes after the 1970s, strongly suggest that the populations of Dolichospermum increased their importance during the 1980s and 1990s (Fig. 4), i.e., during the period coinciding with the appearance of the first surface blooms (Salmaso et al., 1994). Adopting the terminology by Williamson and Fitter (1996), the methods used in this work allowed to identify the period of establishment of self-sustaining and naturalized populations, after a first importing and introduction of the species.

The analysis of the records of sub-fossil akinetes preserved in deep layers of lake sediments represents a powerful and efficient tool to reconstruct the long-term temporal development of potentially toxic Nostocales in water bodies at secular timescales. Akinetes can be pre-

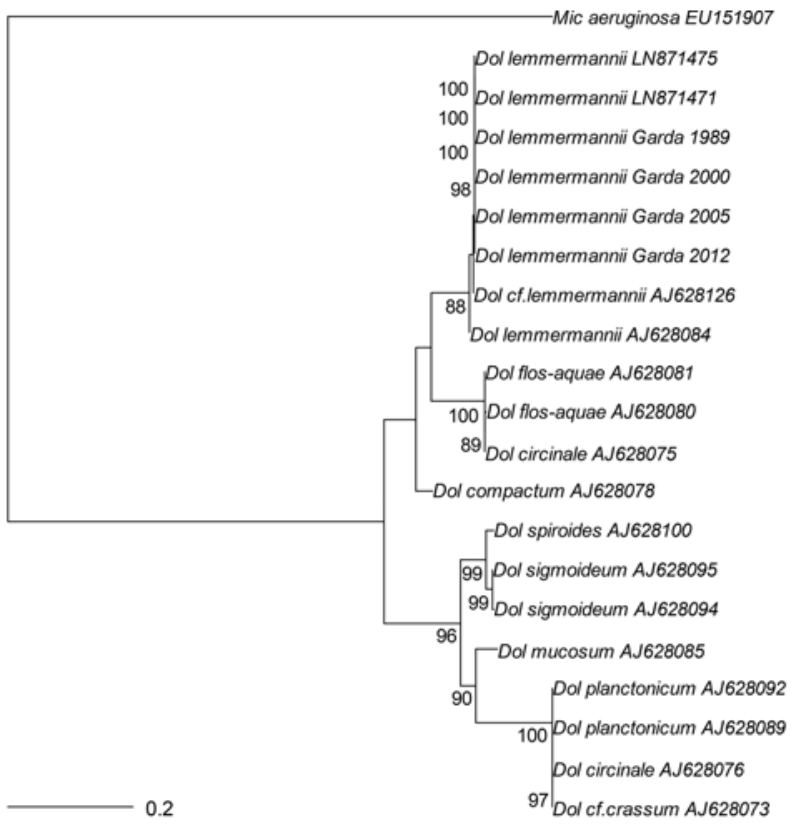

Fig. 5. Maximum likelihood (ML) rooted topology of the four resurrected Dolichospermum lemmermannii strains isolated from the sediments of Lake Garda (1989-2012) and other cyanobacteria (identified by names and accession numbers) based on alignment of the rpoB gene. The $D$. lemmermannii strains isolated from the pelagic samples collected in 2013 and 2014 in Lake Garda have accession numbers LN871471 and LN871475, respectively. Bootstrap values $<70$ were not shown. 
served for very long times in the sediments. van Geel et al. (1994) found that, since 1000 AD on, sub-fossil akinetes of Aphanizomenon and Anabaena were present in enormous quantities in the deep sediment layers of Lake Gosciaz, in Poland. The increase of Nostocales was interpreted as the effect of the intensification of farming and land fertilization, which triggered and intensified the eutrophication of the lake. Similarly, peaks of akinetes of Anabaena (Dolichospermum) in the ancient sediments of Lake Aydat, were found since the 5th century AD (Miras et al., 2015). In Lake Kirmanjärvi, Finland, Kauppila et al. (2012) utilised the mutual changes in the abundance of the akinetes produced by Anabaena and Aphanizomenon to infer the long-term trophic status changes since the mid $16^{\text {th }}$ century.

Akinetes are markedly more resistant than vegetative cells to a wide range of extreme physical, chemical and biotic disturbances (Fay, 1988). Nevertheless, the resistance against specific stressors can be different between species. For example, while the akinetes of Anabaena cylindrica LEMMERMANN were resistant to desiccation, hot temperatures and sunlight (Hori et al., 2003), the akinetes of Anabaena circinalis RABENHORST EX BORNET \& FLAHAULT were susceptible as vegetative cells to desiccation or ultraviolet radiation (Fay, 1988).

When buried in the sediments, the akinetes can retain their viability for decades. In this study, we use the term viability as capability to germinate and to produce new filaments and populations once given the appropriate conditions. In Lake Okaro, germination experiments demonstrated that akinetes of Aphanizomenon issatschenkoi (USAČEV) ProshKINA-LAVRENKo retained their ability to germinate in core sediments dating $120 \mathrm{BP}$ (Wood et al., 2009). Livingstone and Jaworski (1980) demonstrated that akinetes of Aphanizomenon flos-aquae RALFS EX BORneT \& Flahault and Dolichospermum (Anabaena) lemmermannii isolated from 18 and 64 years old sediments were able to germinate, giving rise to viable populations. In the case of Aphan. flos-aquae, the inability to germinate was observed in spite of a large abundance of akinetes in layers older than 18 years. On the one hand, that study demonstrated that akinetes not only have overwintering functions, but are capable of contributing to the long-term survival of Nostocales in lakes. On the other hand, it showed a different ability of akinetes produced by different species to germinate giving rise to mature populations. The implications are clear, suggesting that the germination of akinetes cannot be used to compare the long-term changes in different species of Nostocales. In Lake Garda, the concordance in the temporal distribution of sub-fossil akinetes and germinated cells indicates that the akinetes of $D$. lemmermannii retain the ability to germinate in sediments of at least 35 years old. To date, it is not possible to evaluate how much this approximation is underestimated, because the deepest layer of germinability (Fig. 4B) roughly coincides with the limit of akinete presence (Fig. 4A).

Since akinetes can be resurrected, the genetic structure of sub-fossil populations can be compared with that of modern strains, allowing a more robust assessment of historical fluctuation patterns. In principle, the use of methods of resurrection ecology might allow to reconstruct evolution of organisms by comparing the strains originated from resistance forms with their present descendants (Kerfoot and Lawrence, 2004). The comparison of strains along temporal gradients could help reveal whether direct effects of climate change or other anthropogenic stressors have caused micro-evolutionary processes (Angeler, 2007). The results obtained from sequencing the $r p o B$ gene in populations of Dolichospermum revitalized in the lake sediments spanning 23 years (1989-2012) and isolated from recent pelagic samples did not show any mutation or recombination signal. Actually, previous analyses of other cyanobacteria species (Planktothrix rubescens (DE CANdolle ex Gomont) K. Anagnostidis \& J. KomÁreK) in the large lakes south of the Alps proved that local clonal expansion and recombination processes were influential in affecting among-lake diversity (D'Alelio et al., 2013). Present investigations made on the $16 \mathrm{~S}$ rRNA and $r p o B$ genes of several $D$. lemmermannii isolated from environmental samples are showing the existence of different local clonal populations living in the perialpine lakes (Salmaso et al., 2015a) and in Europe (Capelli et al., unpublished data). Overall, though based on a very limited number of strains, these results could allow to hypothesise a strong founder effect following the beginning of the establishment of D. lemmermannii (between the half of the 1960s and the end of 1970s) and the successive development of the species in Lake Garda. Possibly, these characteristics could allow identifying the geographical path of colonisation by comparing the local clones with those isolated in other European water bodies.

It is widely recognised that the environmental factors mostly affecting the development of cyanobacteria in lakes are eutrophication and high water temperatures (Istvánovics, 2009; O'Neil et al., 2012; Paerl and Paul, 2012). The increase of cyanobacteria following nutrient enrichment ( $\mathrm{P}$ and $\mathrm{N}$ ) has been described in a wide number of studies (see Dokulil and Teubner, 2000), and confirmed by experimental works (Schindler, 2012). The response is strongly dependent from the autecology of the single species, and the distinction is particularly apparent when considering the ability to fix nitrogen (Levine and Schindler, 2011). Nevertheless, more than eutrophication, a number of recent studies highlighted the role of global warming in favouring the recent spread of Nostocales (e.g., Cylindrospermopsis and Aphanizomenon) from tropical to subtropical and temperate regions (Sukenik et al., 2012). 
In warmer environments this group, along with Chroococcales, is favoured by its high replication rates and by the ability to control the vertical positioning in well stratified water columns induced by light availability and nutritional conditions (e.g., carbohydrates content) (Oliver and Walsby, 1984; Reynolds, 2006). The control of the vertical position allows exploiting the full gradients of light and nutrients, giving to Nostocales and other gas-vacuolated species a chief competitive advantage compared to eukaryotic taxa. With the exception of a few localized regions, lake warming was clearly observed and documented all over the world (Sharma et al., 2015). Besides Lake Garda (Fig. 1B), the increase in water temperatures was confirmed also in other lakes of the southern perialpine area. Long-term measurements carried out since the 1970s at spring overturn in lakes Garda, Iseo, Como and Maggiore demonstrated an increase in water temperatures ranging from 0.11 to $0.21^{\circ} \mathrm{C}$ decade $^{-1}$ (Salmaso and Mosello, 2010). These data are confirmed also by models simulating the effects of a climate change scenario in Lake Iseo (Valerio et al., 2015). Along with the rapid increase of air temperatures recorded during the $1960 \mathrm{~s}$, these data could suggest an important role played by climate warming in the establishment and growth of Dolichospermum in Lake Garda. Nevertheless, compared to many other Nostocales (Sukenik et al., 2015), the geographical area of D. lemmermannii was shown to be circumscribed to the temperate and northernmost countries (Komárková, 1988), whereas this species was never found in tropical regions (Komárek, 2013). Conversely, the establishment of this Nostocales in the 1960s does appear rather linked to the increase of phosphorus and to the shift of the lake from a state between ultra-oligotrophy and oligotrophy to oligomesotrophy. The ecological requirements of $D$. lemmermannii have been well described (Cronberg, 1999; Padisák et al., 2008; Reynolds et al., 2002; Salmaso et al., 2015b), conforming completely to this assumption. In fact, this species is well adapted to clear, deep stratifying oligomesotrophic lakes, or mesotrophic, non turbid shallow lakes. Therefore, we could hypothesise that the establishment of this species in Lake Garda might be favoured primarily by the increase of anthropogenic pressure and changes in trophic status. The successive development of this species could have been reinforced by the climate warming in the subalpine area and by the consequent increase in water temperatures. The absence of any consistent change in the long term-availability of $\mathrm{NO}_{3}-\mathrm{N}$ since the 1990s suggests a possible minor role played by nitrogen. Nevertheless, as highlighted in previous works (Salmaso, 2010), owing to the $\mathrm{N}$-fixing abilities of heterocytous species, the low summer concentrations of $\mathrm{N}$ that are usually found in the upper surface layers in lake Garda could be a positive factor for the growth of Dolichospermum in the warmer months.
As demonstrated by the analysis of the long-term phytoplankton data (Salmaso et al., 2015a), the biovolume values of $D$. lemmermannii in the trophogenic layers (0$20 \mathrm{~m})$ of Lake Garda were always low $\left(<50 \mathrm{~mm}^{3} \mathrm{~m}^{-3}\right)$, contributing for a very small fraction to the total annual phytoplankton and cyanobacterial biovolumes (less than $1 \%$ and 5\%, respectively; see also Fig. 2 B,C). The dominant cyanobacterial species in Lake Garda and in the other large lakes south of the Alps is in fact Planktothrix rubescens (Salmaso et al., 2012; Leoni et al., 2014). On the other hand, since the blooms are caused by a rapid vertical movement of filaments present in the euphotic layers, these accumulations provide a false idea of massive cyanobacterial development and growth in the surface waters. These considerations confirm that $D$. lemmermannii should be considered a well established species rather than an invasive or pest species (Williamson and Fitter, 1996; Keller et al., 2011).

We could anticipate that, if the downward trend of $\mathrm{P}$ in Lake Garda will be confirmed, then we could expect a further decrease of cyanobacteria and Nostocales, and a decrease in the frequency of summer water blooms of Dolichospermum. Overall, this should favour the recovery of the lake to near-pristine conditions. Conversely, a further increase in the trophic status, especially if associated with an additional increase in summer water temperatures, could increase cyanobacteria abundances and surface water blooms. However, it is worth to highlight that an excessive increase in nutrients is a deterrent for the development of $D$. lemmermannii, which would be replaced by other cyanobacteria better adapted to mesotrophic and eutrophic conditions, such as different species of Dolichospermum, as well as Aphanizomenon, Microcystis and, provided a sufficient amount of light is present in the metalimnion, P. rubescens. These considerations could be confirmed by the absence of consistent populations and blooms of $D$. lemmermannii in Lake Lugano. The reasons are due to the lower water temperatures and higher mixing that distinguish the epilimnion of this lake (Salmaso et al., 2012) and to the higher trophic status of the trophogenic layers. In fact, the dominant Nostocales in Lake Lugano is Aphan. flos-aquae, a species that is not only well adapted to develop under eutrophic conditions (Reynolds et al., 2002; Salmaso et al., 2015b), but that it is also well fitted to grow in mixed surface layers (Kangro et al., 2007).

\section{CONCLUSIONS}

In this work, we investigated the timing of establishment of the populations of $D$. lemmermannii in Lake Garda by the direct counting of sub-fossil akinetes and by the estimation of the abundances of strains germinated from viable akinetes conserved in the sediments. The two 
techniques provided comparable results, allowing locating the beginning of the establishment of Dolichospermum between the middle of the 1960s and the early 1970s, respectively. The sequencing of the rроB genes in populations of Dolichospermum revitalized in the lake sediments between around 1989 and 2012 and isolated from recent pelagic samples did not show any mutation or recombination, suggesting a strong founder effect following the successive development of the species. The establishment of Dolichospermum in Lake Garda has been linked to the rapid increase of TP in the lake since the 1960s, as inferred from the study of the distribution of sub-fossil diatoms in the core sediment layers. The significant increase in the air and water temperatures observed in the last decades did reinforce and probably increased the effects triggered by anthropogenic eutrophication. If the downward trend of phosphorus that was observed in Lake Garda since the half of the 2000s will continue, then the biomass of cyanobacteria and Nostocales and the frequency of summer water blooms of Dolichospermum should show a further and consistent decrease.

\section{ACKNOWLEDGMENTS}

Investigations in Lake Garda and in the other large lakes south of the Alps were made in the framework of the LTER (Long Term Ecological Research) Italian network, site "Southern Alpine lakes", IT08-000-A (http://www.lteritalia.it/). The activity was supported by $\mathrm{PhD}$ fellowships to C.C. from the E. Mach Foundation Istituto Agrario di S. Michele all'Adige. We thank the European Cooperation in Science and Technology COST Action ES1105 CYANOCOST for networking and knowledge-transfer support. The core sediment in Lake Balaton was collected in the framework of the EU Central Europe project EULAKES (2CE243P3). We are grateful to our colleagues in FEM for their support in the field and laboratory activities, and to the ARPA Veneto for logistic support in the field.

\section{REFERENCES}

Angeler DG, 2007. Resurrection ecology and global climate change research in freshwater ecosystems. J. N. Am. Benthol. Soc. 26:12-22.

Auer I, Böhm R, Jurkovic A, Lipa W, Orlik A, Potzmann R, Schöner W, Ungersböck M, Matulla C, Briffa K, Jones P, Efthymiadis D, Brunetti M, Nanni T, Maugeri M, Mercalli L, Mestre O, Moisselin J-M, Begert M, Müller-Westermeier G, Kveton V, Bochnicek O, Stastny P, Lapin M, Szalai S, Szentimrey T, Cegnar T. Dolinar M, Gajic-Capka M, Zaninovic K, Majstorovic Z, Nieplova E, 2007. HISTALP - historical instrumental climatological surface time series of the Greater Alpine Region. Int. J. Climatol. 27:17-46.
Battarbee R, Jones V, Flower R, Cameron N, Bennion H, Carvalho L, Juggins S, 2001. Diatoms, p. 155-202. in: J. Smol, H.J. Birks, W. Last, R. Bradley and K. Alverson (eds.), Tracking environmental change using lake sediments. 3. Springer

Bennion H, Juggins S, Anderson NJ, 1996. Predicting epilimnetic phosphorus concentrations using an improved diatom-based transfer function and its application to lake eutrophication management. Environ. Sci. Technol. 30:2004-2007.

Callieri C, Bertoni R, Contesini M, Bertoni F, 2014. Lake level fluctuations boost toxic cyanobacterial "oligotrophic blooms". PLoS One 9:e109526.

Carmichael WW, Gorham PR, 1974. An improved method for obtaining axenic clones of planktonic blue-green algae 2. J. Phycol. 10:238-240.

Cerasino L, Salmaso N, 2012. Diversity and distribution of cyanobacterial toxins in the Italian subalpine lacustrine district. Oceanol. Hydrobiol. Stud. 41:54-63.

Chorus I, Bartram J, 1999. Toxic cyanobacteria in water: a guide to their public health consequences, monitoring and management. Available from: http://www.who.int/water_sanitation_health/resourcesquality/toxcyanbegin.pdf

Cronberg G, 1999. Qualitative and quantitative investigations of phytoplankton in Lake Ringsjon, Scania, Sweden. Hydrobiologia 404:27-40.

D'Alelio D, Salmaso N, Gandolfi A, 2013. Frequent recombination shapes the epidemic population structure of Planktothrix (Cyanoprokaryota) in Italian subalpine lakes. J. Phycol. 49:1107-1117.

Danielsen R, 2009. Dissimilarities in the recent histories of two lakes in Portugal explained by local-scale environmental processes. J. Paleolimnol. 43:513-534.

Dokulil MT, Teubner K, 2000. Cyanobacterial dominance in lakes. Hydrobiologia 438:1-12.

Edgar RC, 2004. MUSCLE: multiple sequence alignment with high accuracy and high throughput. Nucleic Acids Res. 32:1792-7.

Faegri K, Iverson J, 1989. Textbook of pollen analysis. Blackburn Press, Caldwell: 340 pp.

Fay P, 1988. Viability of akinetes of the planktonic cyanobacterium Anabaena circinalis. P. Roy. Soc. Lond. B Bio. 234:283-301.

Graham LE, Graham MJ, Wilcox LW, 2009. Algae, 2nd ed. Benjamin Cummings, San Francisco: 720 pp.

Hori K, Okamoto J, Tanji Y, Unno H, 2003. Formation, sedimentation and germination properties of Anabaena akinetes. Biochem. Eng. J. 14:67-73.

Ibelings BW, Backer LC, Kardinaal WEA, Chorus I, 2014. Current approaches to cyanotoxin risk assessment and risk management around the globe. Harmful Algae 40:63-74.

Istvánovics, V, 2009. Eutrophication of lakes and reservoirs, p. 157-164. In: G.E. Likens (ed.), Encyclopedia of inland waters. Elsevier.

Kangro K, Olli K, Tamminen T, Lignell R, 2007. Species-specific responses of a cyanobacteria-dominated phytoplankton community to artificial nutrient limitation in the Baltic Sea. Mar. Ecol.-Prog. Ser. 336:15-27.

Kaplan-Levy RN, Hadas O, Summers ML, Rücker J, Sukenik A, 2010. Akinetes: dormant cells of cyanobacteria p. 5-27. In: E. Lubzens, J. Cerdà and M.S. Clark (eds.), Dormancy and resistance in harsh environments. Springer. 
Kauppila T, Kanninen A, Viitasalo M, Räsänen J, Meissner K, Mattila J, 2012. Comparing long term sediment records to current biological quality element data - Implications for bioassessment and management of a eutrophic lake. Limnologica 42:19-30.

Keller RP, Geist J, Jeschke JM, Kühn I, 2011. Invasive species in Europe: ecology, status, and policy. Environ. Sci. Eur. 23:23.

Kerfoot WC, Lawrence JW, 2004. Experimental paleoecology (resurrection ecology): Chasing Van Valen's Red Queen hypothesis. Limnol. Oceanogr. 49, 1300-1316.

Kim BH, Lee WS, Kim Y-O, Lee H-O, Han M-S, 2005. Relationship between akinete germination and vegetative population of Anabaena flos-aquae (Nostocales, Cyanobacteria) in Seokchon reservoir (Seoul, Korea). Arch. für Hydrobiol. 163, 49-64. doi:10.1127/0003-9136/2005/0163-0049

Komárek J, 2013. Cyanoprokariota. part 3: Heterocytous Genera, in: Süßwasserflora von Mitteleuropa, Band 19/3. Springer.

Komárková J, 1988. Morphological variation in natural populations of Anabaena lemmermannii in respect to existence of Anabaena utermoehlii. Algol. Stud. Hydrobiol. Suppl. Vol. 50/53:93-108.

Kravchuk ES, Ivanova EA, Gladyshev MI, 2006. Seasonal dynamics of akinetes of Anabaena flos-aquae in bottom sediments and water column of small Siberian reservoir. Aquat. Ecol. 40:325-336.

Lee RE, 2008. Phycology, 4th ed. Cambridge University Press, Cambridge: 560 pp.

Leoni B, Garibaldi L, Gulati R, 2014. How does interannual trophic variability caused by vertical water mixing affect reproduction and population density of the Daphnia longispina group in Lake Iseo, a deep stratified lake in Italy? Inland Waters 4:193-203.

Levine SN, Schindler DW, 2011. Influence of nitrogen to phosphorus supply ratios and physicochemical conditions on cyanobacteria and phytoplankton species composition in the Experimental Lakes Area, Canada. Can. J. Fish. Aquat. Sci. 56:451-466.

Livingstone D, 1984. The preservation of algal remains in recent lake sediments, p. 191-20. In: E.Y. Haworth and J.W.G. Lund (eds.), Lake sediments and environmental history. Leicester University Press.

Livingstone D, Jaworski GHM, 1980. The viability of akinetes of blue-green algae recovered from the sediments of Rostherne Mere. Brit. Phycol. J. 15:357-364.

Meeks JC, Campbell EL, Summers ML, Wong FC, 2002. Cellular differentiation in the cyanobacterium Nostoc punctiforme. Arch. Microbiol. 178:395-403.

Mehnert G, Leunert F, Cirés S, Johnk KD, Rucker J, Nixdorf B, Wiedner C, 2010. Competitiveness of invasive and native cyanobacteria from temperate freshwaters under various light and temperature conditions. J. Plankton Res. 32:1009-1021.

Menozzi BI, Zotti M, Montanari C, 2010. A non-pollen palynomorphs contribution to the local environmental history in the Ligurian Apennines: a preliminary study. Veg. Hist. Archaeobot. 19:503-512.

Metcalf JS, Codd GA, 2012. Cyanotoxins, p. 651-675. In: B.A. Whitton (ed.), Ecology of cyanobacteria II. Their diversity in space and time. Springer.

Metcalf JS, Richer R, Cox PA, Codd GA, 2012. Cyanotoxins in desert environments may present a risk to human health. Sci. Total Environ. 421/422:118-123.

Milan M, Bigler C, Salmaso N, Guella G, Tolotti M (2015). Multiproxy reconstruction of a large and deep subalpine lake's ecological history since the Middle Ages. J. Great Lakes Res. (In Press).

Miras Y, Beauger A, Lavrieux M, Berthon V, Serieyssol K, Andrieu-Ponel V, Ledger PM, 2015. Tracking long-term human impacts on landscape, vegetal biodiversity and water quality in the lake Aydat catchment (Auvergne, France) using pollen, non-pollen palynomorphs and diatom assemblages. Palaeogeogr. Palaeoclimatol. Palaeoecol. 424: 76-90.

Misof B, Misof K, 2009. A Monte Carlo approach successfully identifies randomness in multiple sequence alignments: a more objective means of data exclusion. Syst. Biol. 58:21-34.

Mosello R, Giussani G, 1997. [Evoluzione recente della qualità delle acque dei laghi profondi subalpini].[Book in Italian]. Doc. Ist. Ital. Idrobiol. 61:1-228.

Mosello R, Ambrosetti W, Arisci S, Bettinetti R, Buzzi F, Calderoni A, Carrara E, De Bernardi R, Galassi S, Garibaldi L, Leoni B, Manca M, Marchetto A, Morabito G, Oggioni A, Pagnotta R, Ricci D, Rogora M, Salmaso N, Simona M, Tartari G, Veronesi M, Volta P, 2010. [Evoluzione recente della qualità delle acque dei laghi profondi subalpini (Maggiore, Lugano, Como, Iseo e Garda) in risposta alle pressioni antropiche e alle variazioni climatiche].[Article in Italian]. Biol. Ambient. 24:167-177.

O'Neil JM, Davis TW, Burford MA, Gobler CJ, 2012. The rise of harmful cyanobacteria blooms: The potential roles of eutrophication and climate change. Harmful Algae 14:313-334.

Oliver RL, Walsby AE, 1984. Direct evidence for the role of light-mediated gas vesicle collapse in the buoyancy regulation of Anabaena flos-aquae (cyanobacteria). Limnol. Oceanogr. 29:879-886.

Padisák J, Crossetti LO, Naselli-Flores L, 2008. Use and misuse in the application of the phytoplankton functional classification: a critical review with updates. Hydrobiologia 621:1-19.

Paerl HW, Huisman J, 2009. Climate change: a catalyst for global expansion of harmful cyanobacterial blooms. Environ. Microbiol. Rep. 1:27-37.

Paerl HW, Paul VJ, 2012. Climate change: links to global expansion of harmful cyanobacteria. Water Res. 46:1349-63.

Platt Bradbury J, Colman SM, Reynolds RL, 2004. The history of recent limnological changes and human impact on Upper Klamath Lake, Oregon. J. Paleolimnol. 31:151-165.

R Core Team, 2015. R: A language and environment for statistical computing. R Foundation for Statistical Computing, Vienna, Austria.

Rajaniemi P, Hrouzek P, Kastovská K, Willame R, Rantala A, Hoffmann L, Komárek J, Sivonen K, 2005. Phylogenetic and morphological evaluation of the genera Anabaena, Aphanizomenon, Trichormus and Nostoc (Nostocales, Cyanobacteria). Int. J. Syst. Evol. Microbiol. 55:11-26.

Reynolds CS, 1972. Growth, gas vacuolation and buoyancy in a natural population of a planktonic blue-green alga. Freshwater Biol. 2:87-106.

Reynolds CS, 2006. The ecology of phytoplankton. Cambridge University Press, Cambridge: 552 pp.

Reynolds CS, Huszar V, Kruk C, Naselli-Flores L, Melo S, 2002. Towards a functional classification of the freshwater phytoplankton. J. Plankton Res. 24:417-428. 
Salmaso N, 2010. Long-term phytoplankton community changes in a deep subalpine lake: responses to nutrient availability and climatic fluctuations. Freshwater Biol. 55:825-846.

Salmaso N, 2011. Interactions between nutrient availability and climatic fluctuations as determinants of the long-term phytoplankton community changes in Lake Garda, Northern Italy. Hydrobiologia 660:59-68.

Salmaso N, Buzzi F, Garibaldi L, Morabito G, Simona M, 2012. Effects of nutrient availability and temperature on phytoplankton development: a case study from large lakes south of the Alps. Aquat. Sci. 74:555-570.

Salmaso N, Capelli C, Shams S, Cerasino L, 2015a. Expansion of bloom-forming Dolichospermum lemmermannii (Nostocales, Cyanobacteria) to the deep lakes south of the Alps: colonization patterns, driving forces and implications for water use. Harmful Algae 50:76-87.

Salmaso N, Cavolo F, Cordella P, 1994. Fioriture di Anabaena e Microcystis nel Lago di Garda. Eventi rilevati e caratterizzazione dei periodi di sviluppo. Acqua Aria 1:17-28.

Salmaso N, Mosello R, 2010. Limnological research in the deep southern subalpine lakes: synthesis, directions and perspectives. Adv. Oceanogr. Limnol. 1:29-66.

Salmaso N, Naselli-Flores L, Padisák J, 2015b. Functional classifications and their application in phytoplankton ecology. Freshwater Biol. 60:603-6019.

Schindler DW, 2012. The dilemma of controlling cultural eutrophication of lakes. Proc. Biol. Sci. 279:4322-33.

Seymour JR, 2014. A sea of microbes: the diversity and activity of marine microorganisms. Microbiol. Aust. 35:183-187.

Shams S, Capelli C, Cerasino L, Ballot A, Dietrich DR, Sivonen $\mathrm{K}$, Salmaso N, 2014. Anatoxin-a producing Tychonema (Cyanobacteria) in European waterbodies. Water Res. 69: 68-79.

Sharma S, Gray DK, Read JS, O'Reilly CM, Schneider P, Qudrat A, Gries C, Stefanoff S, Hampton SE, Hook S, Lenters JD, Livingstone DM, McIntyre PB, Adrian R, Allan MG, Anneville O, Arvola L, Austin J, Bailey J, Baron JS, Brookes J, Chen Y, Daly R, Dokulil M, Dong B, Ewing K, de Eyto E, Hamilton D, Havens K, Haydon S, Hetzenauer $\mathrm{H}$, Heneberry J, Hetherington AL, Higgins SN, Hixson E, Izmest'eva LR, Jones BM, Kangur K, Kasprzak P, Köster O, Kraemer BM, Kumagai M, Kuusisto E, Leshkevich G, May L, MacIntyre S, Müller-Navarra D, Naumenko M, Noges P, Noges T, Niederhauser P, North RP, Paterson AM,
Plisnier P-D, Rigosi A, Rimmer A, Rogora M, Rudstam L, Rusak JA, Salmaso N, Samal NR, Schindler DE, Schladow G, Schmidt SR, Schultz T, Silow EA, Straile D, Teubner K, Verburg P, Voutilainen A, Watkinson A, Weyhenmeyer GA, Williamson CE, Woo KH, 2015. A global database of lake surface temperatures collected by in situ and satellite methods from 1985-2009. Sci. Data 2:150008.

Sukenik A, Beardall J, Hadas O, 2007. Photosynthetic characterization of developing and mature akinetes of Aphanizomenon ovalisporum (Cyanoprokaryota). J. Phycol. 43:780-788.

Sukenik A, Hadas O, Kaplan A, Quesada A, 2012. Invasion of Nostocales (cyanobacteria) to subtropical and temperate freshwater lakes - Physiological, regional, and global driving forces. Front. Microbiol. 3:86.

Sukenik A, Quesada A, Salmaso N, 2015. Global expansion of toxic and non-toxic cyanobacteria: effect on ecosystem functioning. Biodivers. Conserv. 24:889-908.

Takaichi S, 2011. Carotenoids in algae: distributions, biosyntheses and functions. Mar. Drugs 9:1101-1118.

Thompson R, Clarck M, Boulton S, 2012. Core correlation, p. 415-430. In: H.J. Birks, A.F. Lotter, S. Juggins and J.P. Smol (eds.), Tracking environmental change using lake sediments. 5. Springer.

Tomitani A, Knoll AH, Cavanaugh CM, Ohno T, 2006. The evolutionary diversification of cyanobacteria: molecular-phylogenetic and paleontological perspectives. P. Natl. Acad. Sci. USA 103:5442-7.

Valerio G, Pilotti M, Barontini S, Leoni B, 2015. Sensitivity of the multiannual thermal dynamics of a deep pre-alpine lake to climatic change. Hydrol. Process. 29:767-779.

Van Geel B, Mur LR, Ralska-Jasiewiczowa M, Goslar T, 1994. Fossil akinetes of Aphanizomenon and Anabaena as indicators for medieval phosphate-eutrophication of Lake Gosciaz (Central Poland). Rev. Palaeobot. Palynol. 83:97-105.

Ward DM, Castenholz RW, 2012. Cyanobacteria in geothermal habitats, p. 39-63. In: B.A. Whitton (ed.), Ecology of cyanobacteria II. Their diversity in space and time. Springer.

Williamson M, Fitter A, 1996. The varying success of invaders. Ecology 77:1661-1666.

Wood SA, Jentzsch K, Rueckert A, Hamilton DP, Cary SC, 2009. Hindcasting cyanobacterial communities in Lake Okaro with germination experiments and genetic analyses. FEMS Microbiol. Ecol. 67:252-60. 